\title{
LAUNCHING A SCHOLARLY JOURNAL
}

Received: Sept 15, 2019

Accepted: Sept 30, 2019

IIke Coskun Benlidayi ${ }^{*}$ http://orcid.org/0000-0001-6517-5969

${ }^{1}$ Department of Physical Medicine and Rehabilitation, Cukurova University Faculty of Medicine, Adana, Turkey

\section{*Corresponding author:}

Ilke Coskun Benlidayi, Department of Physical Medicine and Rehabilitation, Cukurova University Faculty of Medicine, Adana, Turkey;

E-mail: icbenlidayi@hotmail.com

Keywords: Medical journalism, Periodicals as topic, Publishing, Scholarly publishing

How to cite: Benlidayi I. C. Launching a scholarly journal. Cent Asian J Med Hypotheses Ethics 2020;1(1):6668. https://doi.org/10.47316/caimhe.2020.1.1.10

"The beginning is the most important part of the work" reads a quote from Plato. Setting a scientific direction or a scholarly project is often complicated and troublesome. Launching a scholarly journal is especially difficult as it may require enormous efforts from numerous contributors and supporters. From the very beginning, successful start-up journals need an editorial team with vast experience of scholarly writing, reviewing, and editing. Having devoted professionals involved at all stages of publishing enables the editors presenting the "journal of our dreams" to the global scholarly community.

One of the requirements for successful editorial team is active involvement of its members in research within the journal's scope of interests. Nowadays, editors are required to be familiar with research reporting guidelines, principles of statistics, and ethics standards, let alone postpublication ethical promotion and scholarly networking norms. Peer-reviewing experience is also becoming increasingly important for meeting high standards of professional editorial teams. Learning from peers' good practices and mistakes rewards the editors in their arduous journal publishing endeavor [1].

A good evidence-based journal currently relies on guidance of several globally recognized organizations, such as the Enhancing the QUAlity and Transparency Of health Research (EQUATOR) Network and the International Committee of Medical Journal Editors (ICMJE) [2, 3]. Ideally, enforcing the reporting standards at the journal launching will pave the way for indexing it by prestigious bibliographic databases later on.

In reality, however, there is still poor awareness of the importance of the reporting standards. A recent study evaluated the endorsement of the STrengthening the Reporting of Observational Studies in Epidemiology (STROBE) statement and its extensions by journals publishing observational 


\section{Central Asian Journal of Medical Hypotheses and Ethics| \\ 2020; Vol 1}

studies [4]. The results pointed to unacceptably low enforcement rates: $13 \%$ of the journals actively endorsed the STROBE whereas $54 \%$ did not refer to it in their instructions. Only $39 \%$ of the journals had any mention of the ICMJE recommendations [4].

Adhering to the globally acceptable standards of publication ethics is strongly advisable for modern science journalism. The Committee on Publication Ethics (COPE) is a global organization with vast experience of guiding journal editors and discussing numerous cases of research misconduct. Joining the COPE and enforcing their recommendations may reward the editor efforts [5].

The editors of the start-up journals often encounter difficulties of attracting their readership. Exploring competitive publishing environment and analyzing practices of other successful journals in their subject area are required from the start. To succeed in the tough competition, the editors should primarily set their journal policies and revise them regularly to meet the high expectations of the global community of editors [6]. The World Association of Medical Editors (WAME) and the Council of Science Editors (CSE) are those prestigious global associations that may be useful for medical editors struggling to achieve high standards [7]. Following their updated resources is proved essential for acquiring editorial credentials [6].

The start-up journal editors may achieve great results with limited resources by properly formulating their aims and targeting specific groups of readers. Although most journals currently tend to be international and global, focusing on local interests and publishing articles read and used by local readership might be a more pragmatic strategy on some occasions.

To sum up, the editors should pass a long way toward establishing a truly useful source of knowledge. With that in mind, it is hoped that the appended cartoon will be perceived by our readers with a sense of humour and optimism. Having scientific dreams and distinguishing reality from mirage will pay off.

\section{REFERENCES}

1. Gasparyan AY. Selecting your editorial board: maintaining standards. J Korean Med Sci 2013;28(7):972973.

2. Enhancing the QUAlity and Transparency Of health Research (EQUATOR) network. Available from: http://www.equator-network.org/ [Accessed July 30, 2019].

3. International Committee of Medical Journal Editors (ICMJE). Avialable from http://www.icmje.org/ [Accessed July 30, 2019].

4. SharpMK, Tokalić R, Gómez G, Wager E, Altman DG, Hren D. A cross-sectional bibliometric study showed suboptimal journal endorsement rates of STROBE and itsextensions. J Clin Epidemiol 2019;107:42-50.

5. Gasparyan AY, Yessirkepov M, Voronov AA, Koroleva AM, Kitas GD. Updated Editorial Guidance for Quality and Reliability of Research Output. J Korean Med Sci 2018;33(35):e247.

6. Suh CO, Oh SJ, Hong ST. Korean association of medical journal editors at the forefront of improving the quality and indexing chances ofits member journals. J Korean Med Sci 2013;28(5):648-650.

7. Gasparyan AY. Familiarizing with science editors' associations. Croat Med J 2011;52(6):735-739.

\section{Ғылыми журналдың ашылуы}

Түйінді сөздер: Медициналық журналистика, Тақырып ретінде мерзімді басылымдар, Баспа, Ғылыми жарияланымдар

Дәйексөз үшін: Бенлайда И.К. Ғылыми журналдың ашылуы. Медициналық гипотеза мен этиканың Орта Азиялық журналы. - 2020. - №1 (1). - С. 66 - 68. https://doi.org/10.47316/cajmhe.2020.1.1.10 


\section{Central Asian Journal of Medical Hypotheses and Ethics| 2020; Vol 1}

\section{Запуск научного журнала}

Ключевые слова: медицинская журналистика, периодика как тема, издательское дело, научные публикации.

Для цитирования: Бенлайда И.К. Запуск научного журнала. Центрально-азиатский журнал медицинских гипотез и этики. - 2020. - №1 (1). - С. 66-68. https://doi.org/10.47316/cajmhe.2020.1.1.10

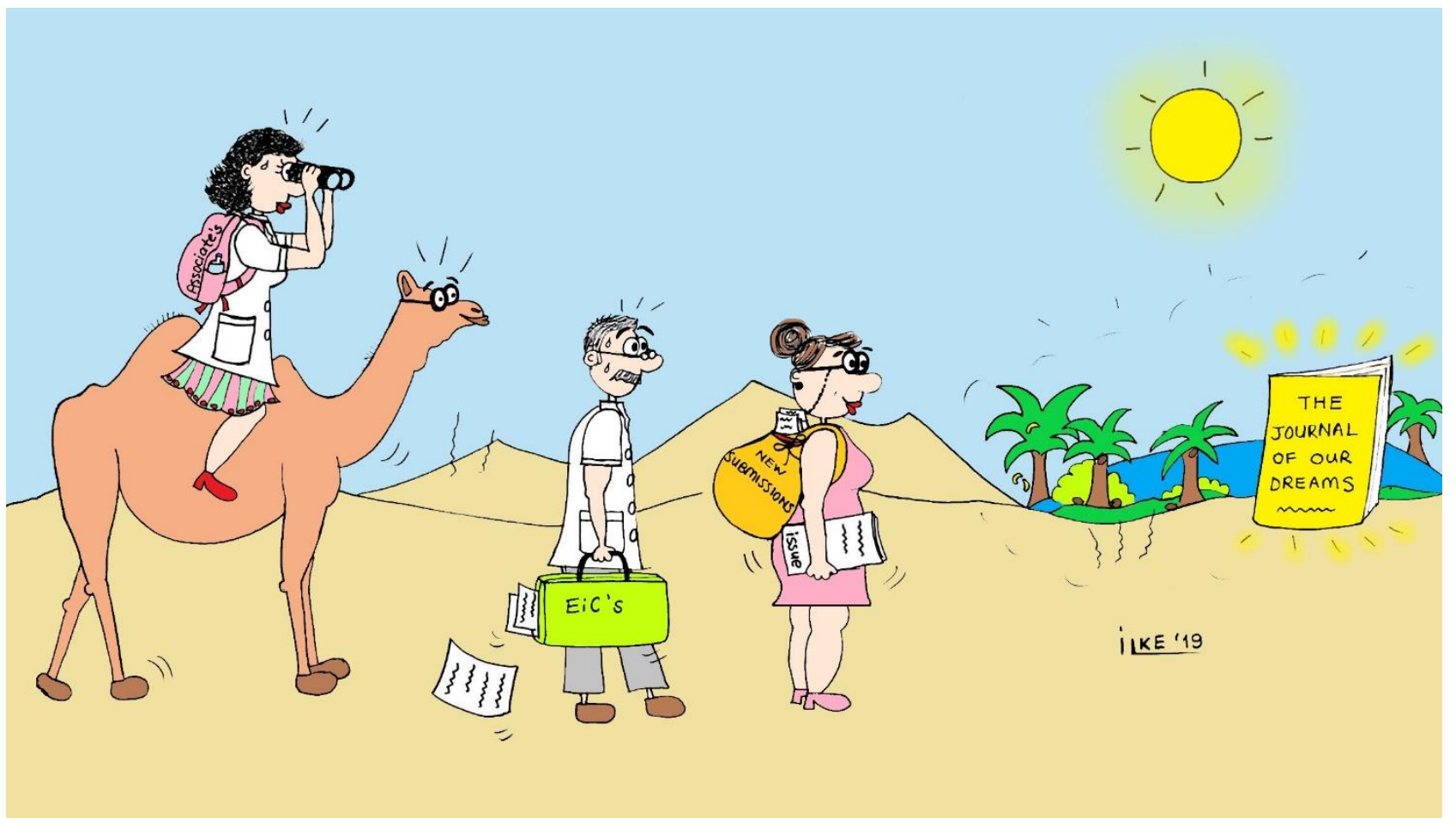

